\title{
Urban-rural variations in health in the Netherlands: does selective migration play a part?
}

\author{
Robert A Verheij, H Dike van de Mheen, Dinny H de Bakker, Peter P Groenewegen, \\ Johan P Mackenbach
}

\begin{abstract}
Study objective-Urban-rural health differences are observed in many countries, even when socioeconomic and demographic characteristics are controlled for. People living in urban areas are often found to be less healthy. One of the possible causes for these differences is selective migration with respect to health or health risk factors. This hypothesis is hardly ever empirically tested. This paper tries to assess the existence of selective urbanrural migration.
\end{abstract}

Design-Health indicators and health risk factors were measured in a 1991 population sample. Moves were registered between 1991 and 1995. Using logistic regression analyses, comparisons were made between, firstly, urban to rural movers and rural to urban movers and secondly, between movers and stayers.

Setting-Region surrounding the city of Eindhoven in south eastern part of the Netherlands.

Subjects-Data were used of 15895 respondents aged 20-74 in 1991. By 1995613 subjects had moved from urban to rural and 191 subjects from rural to urban.

Main results-Bivariate nor multivariate analyses show hardly any differences between movers into urban and movers into rural areas. Bivariate analyses on movers and stayers show that movers are healthier than stayers. However, when socioeconomic and demographic variables are controlled for, movers appear to be less healthy, with the exception of the younger age groups.

Conclusions-Areas that attract many migrants from and lose few migrants to other degrees of urbanicity will in the long run obtain healthier populations, because of demographic and socioeconomic characteristics. However, if these characteristics are accounted for, the opposite is true, with the exception of younger age groups. In extreme cases this may cause spurious findings in cross sectional research into the relation between urbanicity and health. Absolute numbers of migrants need to be very high, however, to make this noticeable at the aggregate level. (F Epidemiol Community Health 1998;52:487-493)

Urban-rural differences in health have been frequently found in many countries. ${ }^{1}$ Such differences are often reported to persist when differences in composition of rural and urban populations are taken into account. There are two possible causes for these differences. Firstly, there may be health effects of locality based factors such as pollution and lifestyles that covary with urbanicity. Secondly, selective migration may play a part. These mechanisms are captured in the breeder and drift hypotheses.

The breeder hypothesis contends that people's health is influenced by locality bound exposure and behaviour. Three sets of causes can be discerned that have a direct or indirect effect on health. Firstly, there are certain health related environmental factors to which people are exposed and that have a direct effect on health. These factors are aspects of the physical as well as social and cultural environments. Obvious examples are high traffic densities and pollution. ${ }^{2}$ Secondly, besides these direct effects, the sociocultural and physical environment also influence health via stress. According to the stress hypothesis, ${ }^{3}$ urban residents are more frequently and more severely confronted with certain types of stressors than rural residents such as higher exposure to neighbourhood noises in urban areas. ${ }^{4}$ This would, then, result in higher levels of psychiatric morbidity and lower levels of well being in the more stressful urban area. The third set of causes indirectly affects people's health: health behaviour. Smoking, drinking, and substance misuse are examples of health behaviour that are typical of urban areas and often associated with urban unconventionalism. ${ }^{5-7}$ However, the relation between place and health may be blurred by a number of factors. ${ }^{8}$ One of these is associated with selective spatial mobility.

The drift hypothesis refers to selection processes that result in a higher concentration of either ill (health selection) or more susceptible persons (selection according to health risk factors). In the first case we speak of direct selection, in the second case of indirect selection. Direct selection would take place if healthy people stay and ill people move, or the other way around. Indirect selection would take place if people with certain health risk factors (for example, smoking, drinking) move to or from specific places. The principle of selective migration was already evident in the Middle Ages when it contributed to the urban concentration of Black Death casualties. ${ }^{9}$ In the mid-nineteenth century Welton, ${ }^{10}$ found that women in better health moved to cities to seek jobs, while the more unhealthy stayed in the villages. More recently, direct as well as indirect selection effects are considered an important reason for urban-rural health differences in the recently published Dutch Social and Cultural 
Report. ${ }^{11}$ Having found area variations in health Ecob concludes that "the area effects found in this study could result either in whole or in part from selective migration". ${ }^{12}$ Fischer $^{13}$ suggests that urban-rural differences in happiness might be explained by "the ability of affluent persons to leave those areas (major cities) in pursuit of the ideal home in the ideal smaller community - and the inability of others to do so".

However, for two reasons there is little empirical evidence with respect to selection effects in the urban-rural distribution of health. Firstly, to investigate selection effects, longitudinal data are needed on large numbers of people, including data on mobility and (past) illness and health risk factors. Only seldom are these demands met. Some cross sectional studies that include limited retrospective information on migration suggest that selection effects are not important. ${ }^{14-16}$ Secondly, longitudinal studies that do exist are concerned with regional differences in general, not urban-rural variations. ${ }^{817-21}$

Findings from a number of longitudinal studies on regional differences indicate that migration can have an impact on the geographical distribution of health. This has been shown with respect to regional variations in birth outcomes in the US ${ }^{22}$; mortality of black people in the $\mathrm{US}^{20}$; pancreatitis incidence in Nottingham $(\mathrm{UK})^{23}$; leukaemia cases in Linköping (Sweden) ${ }^{8}$; mortality from cardiovascular diseases in black people in New York City. ${ }^{24}$

With respect to health selective migration, Fox et $a l^{18}$ found that migrants who had moved only short distances tended to have high mortality and long distance movers have low mortality compared with the population in general. They conclude that selection effects do exist but that "they are not important to regional gradients in mortality" because of the low level of inter-regional migration. Bentham ${ }^{17}$ used 1981 census data from the UK to assess health status and defined movers as those whose 1981 address was not the same as in the 1980 census. It was found (in bivariate analyses) that among younger age groups it were the more healthy that migrated (especially long distance). With respect to the younger age groups, areas with high out migration would then become less healthy. Among elderly people, on the other hand, unhealthy people were more inclined to move. With respect to the elderly, therefore, areas with high out migration would become more healthy. Across all age groups, long distance migrants seem to be healthier than short distance migrants and the general population. Bentham concludes that migration is probably a significant source of error in studies of the associations between disease and environment: "Sometimes the effect will be to obscure real environmental causes of disease. In other circumstances spurious correlations will be produced". ${ }^{17}$

Part of the health differences found by Bentham can possibly be attributed to moving as a life event. The effect of migration as a life event has been found to have a negative influence on mental health status. ${ }^{1425-29}$ But also with respect to other health aspects negative associations were found. People who have recently moved evaluate themselves as less healthy, have more psychosocial problems, higher probability of psychiatric problems, more complaints, and use more health services. $^{3031}$ These findings show that it is necessary to isolate health effects that are not the result of moving as a life event. This can be done by measuring health status before the move was made.

In summary, there is some evidence that selection effects play a part in geographical variations in health. However, the effect of selection on the urban-rural health distribution has not been subject of study before. The purpose of this study is to shed more light on the possible effects of selective migration. It is not our intention to develop a model for explaining urban-rural migration as such, ${ }^{32}$ but to gain insight into the effect of selective migration on urban-rural health differences.

The extent to which selection effects exist in a local situation, is dependent on: the size of migration flows to and from urban and rural areas; the existence of differences in health problem and risk factor prevalence between movers into urban and movers into rural areas; the existence of differences in health problem and risk factor prevalence between urban-rural movers and non-movers. *

Figure 1 illustrates this. In situations of equal flow sizes (cells b and c are of equal size), all that matters are differences in health between cells $b$ and $c$. In a situation of unequal flow sizes (cells $b$ and $c$ are of unequal size), health differences between movers (cells b and c) and non-movers (cells a and b) become important.

Two questions will be considered:

(1) To what extent do movers from urban to rural areas differ from movers in the other direction with respect to health indicators and health risk factors, controlling for demographic and socioeconomic characteristics?

To answer this question, a comparison will be made between cells $\mathrm{c}$ and $\mathrm{b}$ in figure 1 .

(2) To what extent do movers and stayers differ with respect to health indicators and health risk factors, controlling for demographic and socioeconomic characteristics?

This question will be answered by comparing cells $a+d$ with cells $c+b$ in figure 1 .

\section{Methods}

DATA SOURCE

This paper is based on a secondary analysis of the Longitudinal Study on Socio-Economic Health Differences (LS-SEHD). The design and objective of the LS-SEHD are described in detail elsewhere. ${ }^{33}$ The study is based on a cohort of 15-74 year old, non-institutionalised Dutch citizens, living in the city of Eindhoven and surroundings (a region in the south east of the Netherlands, encompassing 17 municipalities, $n=18$ 973, response $70.1 \%$ ). About $68 \%$

*Because they are irrelevant for urban-rural selection effects, non-movers comprise also the (large) category of movers within the same degree of urbanicity. 
Address in 1995

\begin{tabular}{|c|c|c|}
\hline & urban & rural \\
\hline Address in 1991 & $\begin{array}{c}\text { urban } \\
\text { stayers }\end{array}$ & $\begin{array}{c}\text { urban } \\
\text { to rural } \\
\text { movers }\end{array}$ \\
\hline rural & $\begin{array}{l}\text { c } \\
\text { rural } \\
\text { to urban } \\
\text { movers }\end{array}$ & $\begin{array}{c}\text { rural } \\
\text { stayers }\end{array}$ \\
\hline
\end{tabular}

Figure 1 Classification of movers and stayers. Comparisons are made between $b$ and $c$, and between $a+d$ and $b+c$.
Chronic conditions were determinded with a list of 10 serious and 13 less serious disorders. Sumscores of these were dichotomised (present/not present). Subjective health complaints were measured with a list of 13 items commonly used in (Dutch) epidemiological research. ${ }^{35-37}$ The list includes for example headaches, shortness of breath, feelings of fatigue, listlessness. Sumscores were computed with values between zero and five (more than five complaints collapsed into one category).

A number of risk factors were measured in the survey. Smoking habits were dichotomised into cigarette smokers and "other". A composite measure of alcohol consumption was computed based on four questions. This measure was subsequently dichotomised into excessive and not-excessive drinking. ${ }^{38}$ Physical activity was measured on a four point scale, overweight dichotomised into body mass index $>27$ and $<27$. Finally, number of life events in the year before the survey was measured on a nine item scale (a score of more than 3 was collapsed into one category).

In addition, interaction terms were included between the various health indicators and age. This was done for three reasons. Firstly, there is some evidence that the association between health and migration varies between age groups. ${ }^{17}$ Secondly, there is much research on urban-rural health differences that focuses only on specific age groups. Thirdly, preliminary analyses showed that the relation between age and both dependent variables is not linear. Direction of moves varies with age as well, though a pattern cannot be distinguished. Age groups 25-29 more often move out of the city, while the age groups 35-39 and 50-54 move into the city. Interaction terms were computed with three age groups $20-29 ; 30-54 ; 55+$. Age group 30-54 was defined as the reference category. Interaction terms were calculated with dichotomised health indicators to limit the number of interaction terms, facilitate interpretation, and most importantly because our interest is primarily in the extremes. Perceived health was dichotomised into "health less than good" and "health good". The other health indicators were dichotomised already in the main effects analyses.

With respect to interaction terms with health risk factors a similar procedure was followed, with the same three age groups. In computing interaction terms, health risk factors were dichotomised if they were not already in the main effects analyses. Number of life events was dichotomised into $0-1$ and $>2$ respectively. Physical activity was dichotomised into "little/no exercise" and "reasonable/much exercise".

A set of possible confounders was used comprising those most commonly used in cross sectional research on urban-rural health differences. ${ }^{1}$ These include age, marital status, sex, family status, employment status, and education. Table 1 gives the descriptive statistics of all variables. 
Table 1 Descriptive statistics of movers, stayers, movers into urban, and movers into rural areas

\begin{tabular}{|c|c|c|c|c|c|c|}
\hline & $\begin{array}{l}\text { Not moved } \\
\text { between } \\
\text { urban/rural } \\
(n=15090)\end{array}$ & $\begin{array}{l}\text { Moved } \\
\text { between } \\
\text { urban/rural } \\
(n=805)\end{array}$ & $\begin{array}{l}\text { Significance } \\
p<0.05\end{array}$ & $\begin{array}{l}\text { Moved from } \\
\text { urban to } \\
\text { rural } \\
(n=613)\end{array}$ & $\begin{array}{l}\text { Moved from } \\
\text { rural to } \\
\text { urban } \\
(n=191)\end{array}$ & $\begin{array}{l}\text { Significance } \\
p<0.05\end{array}$ \\
\hline \multicolumn{7}{|l|}{ Health indicators } \\
\hline $\begin{array}{l}\% \text { Self perceived health "less than } \\
\text { good" }\end{array}$ & 29.1 & 18.5 & * & 18.7 & 18.1 & \\
\hline$\% \geqslant 1$ Serious chronic conditions & 17.4 & 10.9 & * & 12.1 & 7.3 & \\
\hline$\% \geqslant 1$ Less serious chronic conditions & 39.4 & 34.5 & $\star$ & 34.7 & 34.0 & \\
\hline \multicolumn{6}{|l|}{ Health risk factors } & \\
\hline$\%$ Cigarette smoker & 33.0 & 32.9 & & 34.1 & 29.3 & \\
\hline$\%$ Excessive drinker & 8.2 & 8.2 & & 8.5 & 7.3 & \\
\hline$\%$ Body mass index $>27$ & 19.8 & 12.4 & * & 12.8 & 11.2 & \\
\hline$\%$ Little physical activity/exercise & 16.5 & 15.2 & & 14.7 & 15.7 & \\
\hline Sum score life events $\geqslant 2$ & 11.4 & 14.8 & * & 15.0 & 13.9 & \\
\hline \multicolumn{7}{|l|}{ Demographic } \\
\hline Marital status & & & * & & & \\
\hline$\%$ Married & 72.9 & 39.1 & & 37.4 & 44.5 & \\
\hline$\%$ Not married & 15.4 & 50.1 & & 51.9 & 44.5 & \\
\hline$\%$ Divorced & 6.1 & 8.0 & & 7.7 & 8.9 & \\
\hline$\%$ Widowed & 5.5 & 2.9 & & 3.1 & 2.1 & \\
\hline Mean age in 1991 & 49.2 & 35.9 & & 35.3 & 37.5 & \\
\hline Age in 1991 in five year groups & & & * & & & $\star$ \\
\hline $20-24$ & 6.0 & 27.7 & & 27.1 & 29.8 & \\
\hline $25-29$ & 6.8 & 22.2 & & 24.5 & 15.2 & \\
\hline $30-34$ & 6.5 & 10.8 & & 11.4 & 8.9 & \\
\hline $35-39$ & 6.0 & 5.5 & & 4.9 & 7.3 & \\
\hline $40-44$ & 7.4 & 4.1 & & 4.5 & 2.6 & \\
\hline $45-49$ & 13.4 & 6 & & 5.9 & 6.3 & \\
\hline $50-54$ & 12.9 & 7.5 & & 6.2 & 11.5 & \\
\hline $55-59$ & 12.9 & 5.2 & & 5.4 & 4.7 & \\
\hline $60-64$ & 11.4 & 4.1 & & 3.6 & 5.8 & \\
\hline $65-69$ & 10.2 & 4.0 & & 4.2 & 3.1 & \\
\hline $70-74$ & 6.5 & 3.0 & & 2.4 & 4.7 & \\
\hline$\%$ Female & 51.6 & 48.4 & * & 48.6 & 47.6 & \\
\hline Family type & & & $\star$ & & & \\
\hline$\%$ No children (yet) & 23.7 & 60.2 & & 60.9 & 58.4 & \\
\hline$\%$ Empty nest & 36.0 & 17.7 & & 16.2 & 22.6 & \\
\hline$\%$ With children & 40.4 & 22.1 & & 22.9 & 18.9 & \\
\hline \multicolumn{7}{|l|}{ Socio economic variables } \\
\hline Employment status & & & * & & & \\
\hline$\%$ Employed & 41.9 & 57.0 & & 58.2 & 52.9 & \\
\hline$\%$ Unemployed & 3.3 & 4.2 & & 4.7 & 2.6 & \\
\hline$\%$ Disability pension & 7.4 & 5.3 & & 5.2 & 5.8 & \\
\hline$\%$ Old age pension & 16.1 & 7.7 & & 7.5 & 8.4 & \\
\hline$\%$ Housewife/man & 28.5 & 13.0 & & 12.4 & 15.2 & \\
\hline$\%$ Student & 2.9 & 12.7 & & 11.9 & 15.2 & \\
\hline Education & & & $\star$ & & & \\
\hline \% Primary school & 22.0 & 7.5 & & 8.5 & 4.3 & \\
\hline$\%$ Lower vocational & 24.3 & 12.7 & & 13.2 & 10.6 & \\
\hline$\%$ Lower general & 14.8 & 11.9 & & 10.9 & 15.4 & \\
\hline$\%$ Intermediate vocational & 13.5 & 18.8 & & 18.5 & 19.7 & \\
\hline$\%$ Intermediate general & 6.7 & 10.8 & & 10.7 & 11.2 & \\
\hline$\%$ Higher vocational & 13.5 & 25.5 & & 25.5 & 25.5 & \\
\hline$\%$ University & 5.2 & 12.8 & & 12.7 & 13.3 & \\
\hline
\end{tabular}

STATISTICAL ANALYSES

Two series of multiple logistic regression analyses were carried out. The first series was carried out among movers, with "moved into urban" compared with "moved into rural" as the dependent variable. The second series included all respondents, with "moved" compared with "stayed" as the dependent variable.

Separate analyses were carried out for each health indicator and health risk factor. In each of these the complete set of confounding demographic and socioeconomic variables was entered into the model first.

Secondly, one health indicator or health risk factor was entered in the model together with the associated interaction term. Contributions of each variable in the model are presented in terms of odds ratios. Significance criteria were set at 0.05 .

\section{Results}

Before considering the questions raised above, we tested whether the study population shows indeed the same urban-rural differences in health and risk factor prevalence as usually found in the literature (results not in table 1). As was expected the urban population reports more health problems, suffers more often from serious as well as minor chronic conditions and more often considers their health status "less than good" also when controlling for marital status, age, sex, education, and employment status. Furthermore, the urban population has more smokers and more excessive drinkers, more people who had experienced some major life event(s) recently, fewer people who undertake physical exercise, and more overweight cases (the latter not significantly).

COMPARING DIRECTIONS OF MOVING

Bivariate analyses show (table 1) that there are hardly any differences between movers into rural and movers into urban areas. The only exception is found with respect to age composition, but no clear trend is visible.

Table 2 summarises the results of the logistic regression analyses. Controlling for demographic and socioeconomic differences, no significant differences appear to exist between urban-in and urban-out movers with respect to 
Table 2 Odds ratios of health indicators, risk factors, and interaction terms. Results logistic regression on migration into urban area (max=784)*

\begin{tabular}{|c|c|c|c|}
\hline Health indicators & & OR & $95 \% C I$ \\
\hline \multirow{5}{*}{ Perceived health } & excellent & 1.06 & $0.68,1.64$ \\
\hline & good & 1 & - \\
\hline & reasonable & 1.03 & $0.48,2.23$ \\
\hline & good nor bad & 1.3 & $0.47,2.59$ \\
\hline & bad & 1.52 & $0.31,7.57$ \\
\hline \multirow[t]{2}{*}{ Interaction } & less than good and age $20-29$ & 0.83 & $0.25,2.73$ \\
\hline & less than good and age $\geqslant 55$ & 0.75 & $0.24,2.33$ \\
\hline \multirow[t]{6}{*}{ Complaints } & 0 & 1 & - \\
\hline & 1 & 0.87 & $0.48,1.55$ \\
\hline & 2 & 0.69 & $0.33,1.44$ \\
\hline & 3 & 0.75 & $0.34,1.65$ \\
\hline & 4 & 0.93 & $0.41,2.12$ \\
\hline & $\geqslant 5$ & 1.15 & $0.56,2.35$ \\
\hline \multirow[t]{2}{*}{ Interaction } & $\geqslant 2$ complaints and age $20-29$ & 1.67 & $0.76,3.68$ \\
\hline & $\geqslant 2$ complaints and age $\geqslant 55$ & 1.81 & $0.55,6.03$ \\
\hline \multirow[t]{2}{*}{ Serious chronic condition } & no & 1 & - \\
\hline & yes & 0.43 & $0.15,1.2$ \\
\hline \multirow[t]{2}{*}{ Interaction } & yes and age $20-29$ & 3.27 & $0.73,14.62$ \\
\hline & yes and age $\geqslant 55$ & 0.78 & $0.16,3.75$ \\
\hline \multirow[t]{2}{*}{ Minor chronic condition } & no & 1 & - \\
\hline & yes & 0.85 & $0.47,1.54$ \\
\hline \multirow[t]{2}{*}{ Interaction } & yes and age $20-29$ & 1.11 & $0.49,2.53$ \\
\hline & yes and age $\geqslant 55$ & 1.34 & $0.49,3.71$ \\
\hline \multicolumn{4}{|l|}{ Health risk factors } \\
\hline \multirow[t]{2}{*}{ Smoking } & no & 1 & - \\
\hline & yes & 0.8 & $0.43,1.51$ \\
\hline \multirow[t]{2}{*}{ Interaction } & yes and age $20-29$ & 1.5 & $0.66,3.37$ \\
\hline & yes and age $\geqslant 55$ & 0.78 & $0.21,2.88$ \\
\hline \multirow[t]{2}{*}{ Excessive drinking } & no & 1 & - \\
\hline & yes & 0.66 & $0.24,1.77$ \\
\hline \multirow[t]{2}{*}{ Interaction } & yes and age $20-29$ & 1.15 & $0.28,4.81$ \\
\hline & yes and age $\geqslant 55$ & 2.4 & $0.36,15.86$ \\
\hline \multirow[t]{2}{*}{$\mathrm{BMI}>27$} & no & 1 & - \\
\hline & yes & 0.72 & $0.3,1.68$ \\
\hline \multirow[t]{2}{*}{ Interaction } & yes and age $20-29$ & 1.49 & $0.39,5.65$ \\
\hline & yes and age $\geqslant 55$ & 0.98 & $0.26,3.72$ \\
\hline \multirow[t]{4}{*}{ Physical exercise } & much & 1 & - \\
\hline & moderate & 1.22 & $0.83,1.8$ \\
\hline & little & 1.09 & $0.46,2.57$ \\
\hline & none & 1.81 & $0.69,4.71$ \\
\hline \multirow[t]{2}{*}{ Interaction } & little/moderate and age $20-29$ & 0.86 & $0.29,2.57$ \\
\hline & little/moderate and age $\geqslant 55$ & 0.85 & $0.22,3.19$ \\
\hline \multirow[t]{4}{*}{ Life events ${ }^{\star \star}$} & 0 & 1 & - \\
\hline & 1 & 1.4 & $0.93,2.12$ \\
\hline & 2 & 0.68 & $0.29,1.61$ \\
\hline & $\geqslant 3$ & 0.16 & $0.03,0.85$ \\
\hline \multirow[t]{2}{*}{ Interaction } & $\geqslant 2$ events and age $20-29$ & 2.27 & $0.72,7.16$ \\
\hline & $\geqslant 2$ events and age $\geqslant 55$ & 3.7 & $0.77,17.75$ \\
\hline
\end{tabular}

${ }^{\star}$ Control variables include age in five year classes, sex, marital status, family status, employment status, education. ${ }^{\star}{ }^{\star}$ Overall significance, $\mathrm{p}<0.05$.

health indicators. This indicates that urbanrural health differences cannot be the result of selective migration in a time and a place where inflows and outflows are of equal size. However, there is some evidence that people who have experienced three or more major life events in the year preceding the questionnaire, more often move out of the city than could be expected on the basis of their socioeconomic and demographic characteristics.

COMPARING MOVERS AND STAYERS

Bivariate analyses (table 1) show, firstly, that movers are healthier on all four health indicators. Secondly, concerning health risk factors, movers have fewer overweight people among them and have experienced more life events in the year before the survey. Thirdly, with respect to demographic variables, movers are more often married, younger, and fewer of them are living with their children. Finally, movers are less often old age pensioners, housewives/men, and more often students and employed people.

In the logistic regression analyses, controlling for demographic and socioeconomic characteristics only two health indicators seem to
KEY POINTS

- Movers seem healthier than stayers.

- But controlling for demographic and socioeconomic characteristics, stayers are healthier than movers.

- Suburbanisation can therefore not be an explanation for persistent urban bad health when demographic and socioeconomic variables are controlled for.

distinguish between movers and stayers: perceived general health and number of subjective health complaints (table 3). A high number of subjective health complaints generally seems to increase the odds of moving. Among younger age groups the opposite seems to be true: younger people with relatively many subjective health problems tend to move less often. An overall effect of perceived health was not found. However, as with subjective health complaints, in younger age groups less healthy individuals tend to move less often. It is interesting to note that the main effect results of these analyses are in contrast with those found in bivariate analyses (table 1). Apparently most of the health differences between movers and stayers are accounted for by demographic (and socioeconomic) characteristics.

With respect to health risk factors a significant effect of the number of life events was found. Having experienced two or more major life events in the past year increases the odds of moving. Bivariate analyses showed the same result.

\section{Discussion}

Health differences are frequently found between urban and rural areas, even when demographic and socioeconomic differences between populations are accounted for. This also applies to the LS-SEHD data set used in this paper. These differences may be explained by locality bound exposure and behaviour, or selective migration. In this paper the possible existence of selective moves on the urban-rural distribution of health and health risk factors was investigated.

In the case of even urban and rural inflows and outflows, selection effects can only exist if there is a difference in health and risk factors between movers into rural areas and movers into urban areas. When these flows are not equal in size, selection effects can also result from differences between movers and stayers. A situation like this occurred in the Netherlands in the 1970s, when large scale suburbanisation took place.

Firstly, movers into rural and into urban areas were compared. Bivariate analyses showed no significant differences between these groups, on any of the variables in the study. Controlling for demographic, and socioeconomic factors, logistic regression rendered the same results with respect to health indicators. With respect to health risk factors, there is some indication that people who had experienced many major life events in the 
Table 3 Odds ratios of health indicators, risk factors, and interaction terms. Results logistic regression on probability of moving between urban and rural area (max $=15365)^{\star}$

\begin{tabular}{|c|c|c|c|}
\hline Health indicators & & $O R$ & $95 \% C I$ \\
\hline \multirow[t]{5}{*}{ Perceived health } & excellent & 1 & $0.83,1.21$ \\
\hline & good & 1 & 一 \\
\hline & reasonable & 1.1 & $0.79,1.54$ \\
\hline & good nor bad & 1.04 & $0.69,1.57$ \\
\hline & bad & 1.59 & $0.77,3.28$ \\
\hline \multirow[t]{2}{*}{ Interaction } & less than good and age $20-29$ & 0.57 & $0.35,0.94$ \\
\hline & less than good and age $\geqslant 55$ & 0.94 & $0.57,1.53$ \\
\hline \multirow[t]{6}{*}{ Complaints } & 0 & 1 & - \\
\hline & 1 & 1 & $0.78,1.27$ \\
\hline & 2 & 1.49 & $1.08,2.06$ \\
\hline & 3 & 1.43 & $1.02,2.01$ \\
\hline & 4 & 1.46 & $1.01,2.09$ \\
\hline & $\geqslant 5$ & 1.24 & $0.9,1.7$ \\
\hline \multirow[t]{2}{*}{ Interaction $^{\star \star}$} & $\geqslant 2$ complaints and age $20-29$ & 0.71 & $0.51,1$ \\
\hline & $\geqslant 2$ complaints and age $\geqslant 55$ & 1.32 & $0.81,2.17$ \\
\hline \multirow[t]{2}{*}{ Serious chronic condition } & no & 1 & - \\
\hline & yes & 1.06 & $0.72,1.56$ \\
\hline \multirow[t]{2}{*}{ Interaction } & yes and age $20-29$ & 0.8 & $0.43,1.52$ \\
\hline & yes and age $\geqslant 55$ & 0.76 & $0.43,1.35$ \\
\hline \multirow[t]{2}{*}{ Minor chronic condition } & no & 1 & - \\
\hline & yes & 1.17 & $0.9,1.51$ \\
\hline \multirow[t]{2}{*}{ Interaction } & yes and age $20-29$ & 0.82 & $0.57,1.17$ \\
\hline & yes and age $\geqslant 55$ & 0.97 & $0.62,1.51$ \\
\hline \multicolumn{4}{|l|}{ Health risk factors } \\
\hline \multirow{2}{*}{ Smoking } & no & 1 & - \\
\hline & yes & 0.95 & $0.73,1.24$ \\
\hline \multirow[t]{2}{*}{ Interaction } & yes and age $20-29$ & 0.93 & $0.66,1.32$ \\
\hline & yes and age $\geqslant 55$ & 0.86 & $0.51,1.43$ \\
\hline \multirow[t]{2}{*}{ Excessive drinking } & no & 1 & - \\
\hline & yes & 1.18 & $0.8,1.76$ \\
\hline \multirow[t]{2}{*}{ Interaction } & yes and age $20-29$ & 0.66 & $0.37,1.18$ \\
\hline & yes and age $\geqslant 55$ & 0.76 & $0.33,1.74$ \\
\hline \multirow[t]{2}{*}{$\mathrm{BMI}>27$} & no & 1 & - \\
\hline & yes & 1.09 & $0.77,1.54$ \\
\hline \multirow[t]{2}{*}{ Interaction } & yes and age $20-29$ & 1.06 & $0.6,1.89$ \\
\hline & yes and age $\geqslant 55$ & 0.97 & $0.55,1.69$ \\
\hline \multirow[t]{4}{*}{ Physical exercise } & much & 1 & - \\
\hline & moderate & 1.03 & $0.87,1.22$ \\
\hline & little & 1.34 & $0.93,1.92$ \\
\hline & none & 1.46 & $0.92,2.29$ \\
\hline \multirow[t]{2}{*}{ Interaction } & much/moderate and age $20-29$ & 0.64 & $0.4,1.02$ \\
\hline & much $/$ moderate and age $\geqslant 55$ & 0.76 & $0.42,1.36$ \\
\hline \multirow[t]{4}{*}{ Life events ${ }^{\star \star}$} & 0 & 1 & - \\
\hline & 1 & 0.8 & $0.67,0.96$ \\
\hline & 2 & 1.6 & $1.14,2.25$ \\
\hline & $\geqslant 3$ & 2.04 & $1.23,3.38$ \\
\hline \multirow[t]{2}{*}{ Interaction } & $\geqslant 2$ events and age $20-29$ & 0.64 & $0.4,1.01$ \\
\hline & $\geqslant 2$ events and age $\geqslant 55$ & 0.64 & $0.33,1.26$ \\
\hline
\end{tabular}

${ }^{\star}$ Control variables include age in five year classes, sex, marital status, family status, employment status, education. ${ }^{\star \star}$ Overall significance, $\mathrm{p}<0.05$.

previous year tend to move into the city more than into the countryside. Generally speaking, however, we may conclude that in situations of equal flow sizes, there is a zero-sum exchange of populations with respect to health and health risk factors.

Secondly, movers and stayers were compared. Bivariate analyses showed that movers are healthier on all four indicators. This was also found by Bentham, ${ }^{17}$ who reported lower morbidity (percentage temporarily sick men) among long distance movers as compared with the general population. Similarly, Fox et $a l^{18}$ found lower mortality for interregional migrants. With respect to health risk factors the only difference was found in body mass index and number of life events. People who are overweight are more often stayers. In addition, movers are more often not married or divorced, younger of age, without children, with employment, students, and higher educated. Multivariate logistic regression showed that differences in prevalence of chronic conditions between movers and stayers are attributable to demographic and socioeconomic variations. In contrast with the bivariate findings, the multi- variate results show a positive effect of the number of complaints on the probability of moving. People with more complaints are more inclined to move. Regarding health risk factors movers and stayers seem to differ only in number of life events. Having experienced more than two life events in the previous year increases the probability of moving. Changes in life circumstances such as death of a spouse, unemployment or divorce provoke changes of address.

We suspected age dependent relations between health indicators and migration. Based on the literature we expected a negative association between health and migration among younger people, and a positive among older age groups. This expectation was partly confirmed. Younger age groups with relatively bad perceived general health are less inclined to move than would have been expected based on their age and health status alone. With respect to the number of health complaints experienced a similar result was found, though only at the $10 \%$ significance level. The age varying effect may be related to reasons for moving. Younger people tend to move more often for reasons of work or study, ${ }^{32}$ which are positively related to health. However, this explanation needs further investigation.

In summary, areas that attract many migrants from and lose few migrants to other degrees of urbanicity will in the long run obtain healthier populations. In other words, in times of suburbanisation, rural areas will obtain healthier populations. However, if socioeconomic and demographic differences between movers and stayers are accounted for, the opposite will be true and cities will attain healthier populations. Only areas that attract young migrants may in the long run see a growing number of relatively healthy people in younger age groups.

Absolute numbers of movers need to be very high to make these effects noticeable at the aggregate level, however. A situation like this occurred in the 1970s in the Netherlands, the high tide of urban outflow of higher income groups and families with children. It is sometimes contended that urban-rural health differences partly originate from this period. ${ }^{11}$ Our analyses suggest this can never explain persisting health differences when socioeconomic and demographic variations are controlled for. If anything, urban health improved rather than detoriated in this period if socioeconomic and demographic differences are accounted for and assuming that the relations between health and migration are the same now as they were in the 1970s.

To make the effect of selective migration noticeable at the aggregate level, it is also required that health indicators be consistent in time: health status before moving house needs to be highly correlated with health status after moving. This may not always be the case.

This study is limited in several respects. Firstly, we were able to consider only a limited set of health indicators. It is possible that using indicators of well being or mental health will lead to different results. It is also important to 
note that the survey approach used here fails to include real problem cases like people with schizophrenia, the homeless, and drug addicts who are considered typical of urban areas. Selective migration may play a more important part here.

Secondly, results of this study are difficult to generalise to other spatial levels of analysis or other spatial categorisations. Selective moves may for example be relevant for health differences between neighbourhoods. ${ }^{11}{ }^{39}$ Furthermore, finding no selection processes with respect to urbanicity does not preclude their existence with respect to other spatial characteristics such as area deprivation. Furthermore, it should be noted that this study was limited to a small part of the Netherlands. The extent to which our findings can be generalised to other parts of the Netherlands is not known. We have no reason to believe that the relations between health and migration in the Eindhoven area are very different from those in other major towns in the Netherlands. However, occupational, demographic, and other peculiarities might make an exception of the three largest towns (Amsterdam, The Hague, Rotterdam). It is even more hazardous to generalise our findings to other countries. The Netherlands is characterised by a relatively even distribution of health and other services. Even specialised health services are usually within easy reach. In all Dutch municipalities, $99 \%$ of the population are closer than 30 kilometres to a hospital. There are many countries in which this is not the case. In such a situation the presence of health problems may well be a reason for moving into urban areas. Furthermore, the nature and definition of urban areas varies greatly between countries. This is evident between, for example, the USA and the Netherlands, but even within Europe there are differences in what is called urban and what rural. ${ }^{40}$

Thirdly, it should be noted that a high number of analyses were carried out in this study. Together with the used significance level of 0.05 , this implies that there is a risk that the results are influenced by chance capitalisation.

Despite its shortcomings, however, this paper represents the first study in which the geographical drift hypothesis is empirically tested for urban-rural health differences. Similar studies should be carried out to determine its relevance in other regions, countries, and time periods.

Funding: this study was supported by a grant from the Netherlands Organisation for Scientific Research.

1 Verheij RA. Explaining urban-rural variations in health: a review of interactions between individual and environment. review of interactions between
Soc Sci Med 1995;42:923-35.

2 Green M. Air pollution and health. BMF 1995;311:401-2.

3 Marsella AJ. Urbanization and mental disorders: an overview of Marsella AJ. Urbanization and mental disorders: an overview of theory and research, and recommendations for interventions and
research. Monograph of the Mental Health Division. Geneva: research. Monograph of the Mental Health Division. Geneva:
WHO, 1990.

4 Central Bureau of Statistics. De leefsituatie van de Nederlandse bevolking, 1994. Kerncijfers. Voorburg/Heerlen: Centraal Bureau voor de Statistiek, 1995.

5 Fischer CS. The subcultural theory of urbanism: a twentieth-year assessment. Am f Sociol 1995;101:543-77.

6 Garretsen HFL, Raat H. Urban health in the Netherlands: health situation, health care facilities an public health policy. Health Policy 1991;18:159-68.
7 Reijneveld SA. The measurement of local public health status of an urban population. [Ph D thesis.] Amsterdam: University of Amsterdam, 1995

8 Schaerström A. Pathogenic paths? A time geographical approach in medical geography. Lund: Lund University Press, 1996.

9 Brunt L. Stad. Amsterdam/Meppel: Boom, 1996.

10 Welton TA. On the effects of migrations in distrubing local rates of mortality, as exemplified in the statistics of London and the surrounding country, for the years 1851-1860. fournal of the Institute of Actuaries 1872;16:153.

11 Sociaal en Cultureel Planbureau. Sociaal en cultureel rapport. Rijswijk: Sociaal en Cultureel Planbureau/VUGA, 1996.

12 Ecob R. A multilevel modelling approach to examining the effects of area of residence on health and functioning. $\mathcal{F} R$ Statist Soc A 1996;159:61-75.

13 Fischer CS. To dwell among friends. Chicago: University of Chicago Press, 1982

14 Blazer D, George LK, Landerman R, et al. Psychiatric disorders. A rural/urban comparison. Arch Gen Psychiatry 1985;42:651-6.

15 Lewis G, David A, Andreasson S, et al. Schizophrenia and city life. Lancet 1992;340:137-40.

16 Diderichsen F, Janlert U. Effects of economic change on male morbidity in neighbouring industrial and rural municipalities in northern Sweden. $\mathcal{F}$ Epidemiol Community Health 1992;46:605-7.

17 Bentham G. Migration and morbidity: impications for geographical studies of disease. Soc Sci Med 1988;26:49-54

18 Fox AJ, Goldblatt PO, Adelstein AM. Selection and mortality differentials. F Epidemiol Community Health 1982;36:6979.

19 Strachan DP, Golding J, Anderson HR. Regional variations in wheezing illness in British children: effect of migration during early childhood. I Epidemiol Community Health 1990;44:231-6.

20 Greenberg M, Schneider D. Region of birth and mortality of blacks in the United States. Int F Epidemiol 1992;21:324-8.

21 Jones TL, Shih CH, Thurston DH, et al. Selection bias from differential residential mobility as a explanation for associations of wire codes with childhood cancer. $7 \mathrm{Clin}$ Epidemiol 1993;46:545-8.

22 Khoury MJ, Stewart W, Weinstein A, et al. Residential mobility during pregnancy: implications for environmental teratogenesis. [Published erratum appears in J Clin Epidemiol 1988;41:617]. F Clin Epidemiol 1988;41:15-20.

23 Giggs JA, Bourke JB, Katschinski B. The epidemiology of primary acute pancreatitis in Greater Nottingham: 19691983. Soc Sci Med 1988;26:79-89.

24 Fang J, Madhavan S, Alderman M. The association between birthplace and mortality from cardiovasular causes among black and white residents of New York City. $N$ Engl $f$ Med 1996;335:1545-51.

25 Krout JA. Rural versus urban differences in health dependence among the elderly population. Int F Aging Hum Dev $1989 ; 28: 141-56$

26 Neff JA, Husaini BA. Urbanicity, race, and psychological distress. F Community Psychol 1987;15:520-36.

27 Reitzes DC, Mutran E, Pope H. Location and well-being among retired men. f Gerontol: Soc Sci 1991;46:195-203.

28 Rosenberg EE, Steinert YE. Psychosocial problems: what help do rural and urban patients want from their family physicians? Can Med Assoc f 1987;136:137-41.

29 Zahner GEP, Jacobs JH, Freeman DH Jr, et al. Rural-urban child psychopathology in a northeastern U.S. state: 1986-1989. I Am Acad Child Adolesc Psychiatry 1993;32: 378-87.

30 Thomassen JFM. Mobiliteit en gezondheid. Huisarts en Wetenschap 1978;21:85-92.

31 Moll van Charante AW. Ziektegevoel, ziektegedrag. Een exploratieve analyse van het ziektegedrag in 163 gezinnen gedurende de eerste twee jaren in een hoogbouw meergezinswoning. [Ph D thesis.] Meppel: Krips Repro, 1980.

32 Mulder CH. Migration dynamics: a life course approach. $[\mathrm{PhD}$ thesis.] Amsterdam: Thesis Publishers, 1993.

33 Mackenbach JP, Mheen $\mathrm{H}$ van de, Stronks K. A prospective cohort study investigating the explanation of socioeconomic inequalities in health in the Netherlands. Soc Sci Med 1994;38:299-308.

34 Dulk CJ den, Stadt H, Vliegen JM. Een nieuwe maatstaf voor stedelijkheid: de omgevingsadressendichtheid [New measure for degree of urbanisation: the address density of the surrounding area]. Mndstat bevolk 1992;7:14-22.

35 Dirken JM. Het meten van stress in industriële situaties. Groningen: Wolters, 1967.

36 Sikkel D. Een verkorting van de VOEG-schaal. Sociaal Cultureel Kwartaalbericht 1980;6:9-11.

37 Joosten J, Drop MJ. De betrouwbaarheid en vergelijkbaarheid van drie versies van de VOEG. Gezondheid en Samenleving 1987;8:251-65.

38 Garretsen HFL. Probleemdrinken. [PhD thesis.] Lisse: Swets en Zeitlinger, 1983.

39 Reijneveld SA. Causes of death contributing to urban socioeconomic mortality differences in Amsterdam. Int $\mathcal{F}$ Epidemiol 1995;24:740-9.

40 Pumain D, Saint-Julien T, Cattan N, et al. The statistical concept of the town in Europe. Brussels: Eurostat, 1992. 